\title{
The Relationship Between the Type of Parkinson's Disease and Entrapment Neuropathy in the Upper Extremities
}

\author{
Parkinson Hastalı̆̆ı Tipi ile Üst Ekstremite Tuzak Nöropatisi Arasındaki İlişkinin
} Araştırılması

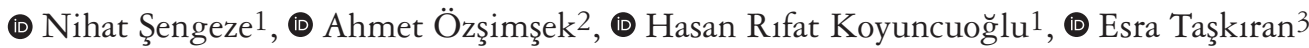 \\ 1 Suleyman Demirel University Faculty of Medicine, Department of Neurology, Isparta, Turkey \\ 2Alanya Alaaddin Keykubat University Faculty of Medicine, Department of Neurology, Antalya, Turkey \\ ${ }^{3}$ Antalya Training and Research Hospital, Clinic of Neurology, Antalya, Turkey
}

\begin{abstract}
Objective: Parkinson's disease (PD) is one of the common neurodegenerative disorders in the community. Compressive neuropathy (CN) is one of the conditions that negatively affect workforce and decreases the quality of life. We aimed to investigate the effect of repetitive mechanical movement on tremor dominant (TD) or akinetic-rigid syndrome (ARS) PD and CNs, particularly, the relationship between CN and two types of PD. In addition, we aimed to evaluate the relationship between $\mathrm{CNs}$ and the affected side at the onset and during the disease in both types of PD.

Materials and Methods: Patients with PD who presented to our clinic from October 2017 to September 2018 were enrolled in the study. All patients who underwent electromyography to investigate $\mathrm{CN}$ were included in the study. The Padua classification was used in the carpal tunnel and cubital tunnel syndrome and electrophysiological findings were classified according to age and gender. According to the disease duration, patients were compared within the two groups as less than 3 years and $\geq 3$ years. Patients were examined in two groups according to the TD and ARS type of PD and initially affected side.

Results: A total of 71 patients suffering from PD were enrolled in the study, wherein 57 (80.3\%) were TD, and 14 were (19.7\%) ARS. An increased risk of developing carpal tunnel syndrome (CaTS) was found in the TD group with a disease duration of $\geq 3$ years $(\mathrm{p}=0.026)$.

Conclusion: No relationship was found between the two different types of PD or the affected side and the type of CN. However, the risk of CaTS increased in TD PD over the 3 years.
\end{abstract}

Keywords: Parkinson disease, compressive neuropathies, carpal tunnel syndrome, cubital tunnel syndrome, akinetic-rigid and tremor-dominant parkinsonism

Öz

Amaç: Parkinson hastalığı $(\mathrm{PH})$ toplumda sık görülen nörodejeneratif hastalıklardan biridir. Tuzak nöropatiler (CN) ise iş gücünü olumsuz etkileyen ve yaşam kalitesini düsüren hastalıklardır. Bu çalışmada tremor gibi tekrarlayan mekanik hareketin, tremor baskın (TD) veya akinetik-rijit (ARS) PH tipinde ve CN üzerindeki etkisini araştırmayı amaçladık. Başka bir deyişle, CN ile iki tip PH arasındaki ilişkiyi incelemek istedik. Bununla beraber her iki PH tipinde, hastalı̆̆ın başlangıcında ve hastalık sırasında etkilenen vücut tarafı ile CN’ler arasındaki ilişkiyi değerlendirdik.

Gereç ve Yöntem: Ekim 2017 ile Eylül 2018 arasında PH tanısı olan hastalar çalışmaya dahil edildi. Yaş ve cinsiyete göre sınıflandırılan karpal tünel ve kübital tünel sendromu elektrofizyolojik bulgularında Padua sınıflandırması kullanıldı. Tüm olgular, hastalık süresine göre üç yıl ve altında ve üç yıl üzeri olarak iki grup şeklinde incelendi. Olgular PH'nin TD ve ARS tipine göre ve hastalı̆̆ın ilk tutulum tarafına göre iki grup olarak değerlendirildi.

Bulgular: Toplam 71 PH çalışmaya dahil edildi. Hastaların 57’si $(\% 80,3)$ TD ve 14’ü $(\% 19,7)$ ARS idi. Üç yıl ve üzeri dönemde TD hasta grubunda karpal tünel sendromu (CaTS) gelişme riskinde artı̧̧ saptandı $(\mathrm{p}=0,026)$.

Sonuç: PH'nin iki farklı tipi veya etkilenen vücut tarafı ile CN'nin tipi arasında bir ilişki saptanmadı. Ancak, üç yıl ve üzeri süreçte tremor dominant PH'de CaTS riski artmıştır.

Anahtar Kelimeler: Parkinson hastalı̆̆ı, tuzak nöropatiler, karpal tünel sendromu, kübital tünel sendromu, akinetik-rijit ve tremor dominant parkinsonizm

Address for Correspondence/Yazışma Adresi: Nihat Şengeze MD, Suleyman Demirel University Faculty of Medicine, Department of Neurology, Isparta, Turkey Phone: +90 2464417280 E-mail: nihatsengeze@yahoo.com ORCID: orcid.org/0000-0002-2821-3708

Received/Geliş Tarihi: 20.10.2020 Accepted/Kabul Tarihi: 13.04.2021

${ }^{\circ}$ Copyright 2021 by Turkish Neurological Society

Turkish Journal of Neurology published by Galenos Publishing House. 


\section{Introduction}

Parkinson's disease (PD) is one the most common neurodegenerative diseases with a prevalence of $0.3 \%$ in the population and $\sim 2 \%$ over 65 years. PD is characterized by a clinical syndrome, including four cardinal features, which are bradykinesia, rigidity, resting tremor, and postural-gait impairment. PD tremor is unilateral in onset and increases with rest $(1,2)$.

$\mathrm{PD}$ is divided into two types according to the predominant clinical signs, which are the akinetic-rigid syndrome (ARS) and tremor dominant (TD). A clear clinical proof shows that different subtypes of PD have different clinical progressions and prognoses (3).

Compressive neuropathy $(\mathrm{CN})$ is one of the conditions that negatively affects workforce and decreases the quality of life. Symptoms range from pain and sensory symptoms (hypesthesia, paresthesia, or anesthesia) to motor movement disruptions and permanent superficial sensation loss. $\mathrm{CN}$ is mostly observed in the upper extremities compared with the lower extremities (4).

Carpal tunnel syndrome (CaTS) is one of the most common types of CNs. Cubital tunnel syndrome [(CuTS)-ulnar neuropathy at the elbow] is the second most common $\mathrm{CN}$ of the upper extremity (5).

A high prevalence of chronic nerve compression was found in the upper extremity. The prevalence of CaTS is approximately $4 \%$ in the normal population. Repetitive movements and some other traumatic movement syndromes are generally associated with most CNs (4). Tremor is a common PD symptom. Nerve compression in the wrist area is rare since tremor is observed on the fingers rather than the wrist area (6).

The hypothesis that needs investigation is whether rigidity and bradykinesia are the confounding factors in the pathogenesis of median or ulnar nerve entrapment in CNs. Both of the upper extremity $\mathrm{CN}$ etiologies claim that symptoms vary with hand activity modifications. This study aimed to investigate the effect of repetitive mechanical movement of TD and ARS type of PD on predisposing CNs. Particularly, the relationship between $\mathrm{CN}$ and two types of PD at the onset and during the disease was investigated.

\section{Materials and Methods}

\section{Patients}

From October 2017 to September 2018, patients presented to Suleyman Demirel University Hospital and Usak Medical Park Hospital were enrolled in the study. Patients diagnosed with TD or ARS of PD were eligible for the study.

Patients diagnosed using the United Kingdom PD Society Brain Bank Clinical Diagnosis Criteria were included in the study. Patients who were admitted to the hospital, with PD diagnosis and followed for at least 2 years, were evaluated by two neurologists and were included in the study. Exclusion criteria were as follows:

- Patients whose symptoms mimicked CN with clinical or electrophysiological evidence of other disease conditions (such as radiculopathy, polyneuropathy, orthopedic or physical abnormalities),

- Patients who were taking medicine (vitamin B complex and steroids) before or during the study period, and
- Patients who had a systemic disease known to cause $\mathrm{CN}$ (such as diabetes, hypothyroidism, rheumatoid arthritis, kidney failure, cervical polyradiculopathy, and traumatic nerve damage).

All patients who received drug therapy for PD were evaluated especially in the "on" condition. The Hoehn and Yahr (H\&Y) scale was used to determine PD severity and disability.

The most affected side and predominant motor signs at the onset were detected by PD evaluation. Later, each patient was categorized based on the severity of symptoms, considering the $\mathrm{H} \& \mathrm{Y}$ scores, symptoms of tremor or rigidity, and disease duration. Patients were then divided into two main groups as TD and ARS. Electrophysiologic and clinical parameters were statistically compared in the two groups. Patient demographic parameters and medical history were collected at baseline. In addition, all patients underwent a complete neurological examination and electrodiagnostic study.

\section{Nerve Conduction Study (NCS)}

Sensory nerve (SNCV) and also motor nerve conduction (MNCV) velocities were measured with an electroneuromyography (ENMG) machine at room temperature $\left(24^{\circ} \mathrm{C}\right)$. A warm compress was applied over cold extremities for NCS. NCS (both median and ulnar nerve) was bilaterally performed in all patients applying the standard electrophysiologic techniques with supramaximal percutaneous stimulation. Sensory responses were obtained by antidromic stimulation. Either the ring or surface electrodes were placed on digit II or $\mathrm{V}$ and SNCV were calculated in both nerves between the wrist and digit II or between the wrist and digit V by determining the onset of sensory nerve action potentials (SNAPs). The SNAP response of the median nerve was recorded across the wrist with the active recording surface electrode, $14 \mathrm{~cm}$ far from the stimulator cathode electrode. In addition, median sensory conduction from the palm to the wrist $(\mathrm{P}-\mathrm{W})$ was measured over an $8-\mathrm{cm}$ conduction distance with electrical stimulation from the palm. The SNAPs at the P-W and the finger to wrist (F-W) were recorded in the same manner. The voltage used for stimulation was increased until the SNAPs reached their maximum amplitude in both techniques used for median nerve sensory assessment. MNCV was determined in both median nerves by wrist stimulation electrode. Distal compound motor action potential (CMAP) of the median nerve was obtained by wrist stimulation and recording at abductor pollicis brevis muscle with cathodes at least $8 \mathrm{~cm}$ apart. Distal CMAP of the ulnar nerve was obtained by medial wrist stimulation and recording at abductor digiti minimi muscle with cathodes $8 \mathrm{~cm}$ apart. For the study, these results were compared between hands with TD and ARS PD. No patient underwent needle ENMG.

ENMG criteria in median neuropathy diagnosis were as follows:

- Prolonged distal motor latencies of the median nerve of $\geq 4.2$ $\mathrm{m} / \mathrm{s}$,

- Decreased SNCV of $\leq 40 \mathrm{~m} / \mathrm{s}$ for the F-W segment and $\leq 40$ $\mathrm{m} / \mathrm{s}$ for the P-W segment,

- Decreased CMAP amplitude of $5 \mathrm{mV}$ and a SNAP amplitude of $10 \mu \mathrm{V}$.

The ENMG criteria defined for ulnar neuropathy diagnosis were as follows:

- Slowing of MNCV ( $<40 \mathrm{~m} / \mathrm{s})$ from above-elbow (AE) to below-elbow (BE) segments. 
- Reduced MNCV of AE to BE segment $>10 \mathrm{~m} / \mathrm{s}$ compared to $\mathrm{BE}$ to wrist (W) segment and with conduction block or temporal dispersion indicative of focal demyelination.

The Padua classification in CaTS and CuTS electrophysiological findings were used (7).

According to the disease duration, patients were compared within the two groups as less than 3 years and $\geq 3$ years. Patients were examined in two groups according to the TD and ARS type of PD and the initially affected side.

\section{Statistical Analysis}

The normality of the distribution of continuous variables was tested using the Shapiro-Wilk test. Mann-Whitney U test was used to compare two independent groups of variables with the abnormal distribution. The chi-square test was utilized to assess the relationship between the categorical variables. A weighted mean of the sensitivity, specificity and odds ratios with $95 \%$ confidence intervals were calculated. Descriptive statistics were presented as frequency, percentage (\%), median (25-75\%), and mean \pm standard deviation. Statistical analysis was performed using the Statistical Package for the Social Sciences for Windows version 22.0 and a $\mathrm{p}$ value of $<0.05$ was accepted as statistically significant.

\section{Ethics Statement}

Approval with reference number 203 was obtained on November 16, 2017, from the Suleyman Demirel University Faculty of Medicine Ethics Committee for the study. This study followed the rules of the 2008 Declaration of Helsinki.

\section{Results}

During the study period, a total of 71 patients with PD were enrolled in the study, wherein $57(80.3 \%)$ were TD type and 14
(19.7\%) were ARS. The mean age was $71.2 \pm 8.6$ years, and 28 (39.4\%) of the patients were women. The mean PD duration was $3.1 \pm 2.4$ years, whereas the initial PD motor symptoms started on the right side in 47 patients $(66.2 \%)$ and on the left side in 24 patients $(33.8 \%)$.

Of the 71 patients, $10(14.1 \%)$ had a history of dyskinesia. Of the 60 patients with tremor symptoms, $39(65 \%)$ had rest tremor only and $21(35 \%)$ had rest, action, and postural tremor altogether.

Table 1 shows the baseline characteristics of all patients enrolled in the study.

The two groups of PD were compared regarding the baseline characteristics shown in Table 1. A significant difference was found between the two groups in terms of the H\&Y stage and tremor symptom $(\mathrm{p}=0.001)$.

Patient evaluation according to the $\mathrm{H} \& \mathrm{Y}$ scale stage revealed that $17(23.9 \%)$ patients were in stage $1,31(43.7 \%)$ in stage 2, and $23(32.4 \%)$ in stage 3 and above.

An NCS was performed in 71 patients, wherein CaTS was diagnosed in 32 patients (45.1\%) and CuTS in 14 patients (19.7\%).

Of the 55 examined hands with CaTS, 28 (51\%) were on the right and 27 were $(49 \%)$ on the left. Of the total 18 hands with CuTS, $9(50 \%)$ were on the right and $9(50 \%)$ were on the left. Table 2 shows the relationship between the initially affected side and the development of entrapment neuropathy. No significant difference was found between the two groups in terms of affected hand and types of $\mathrm{CN}$ (CaTS and CuTS) ( $\mathrm{p}=0.679$ and $\mathrm{p}=0.187$, respectively).

Table 3 shows the relationship between the disease duration and $\mathrm{CN}$ development. Disease duration of $\geq 3$ years was associated with a higher risk of developing CTS in the TD group $(\mathrm{p}=0.026)$ (Figure 1). However, no significant increase was found in the frequency of CaTS in the ARS group. No significant difference was found in terms of presence of CuTS for both groups.

\section{Table 1. Baseline characteristics of patients in the two groups of Parkinson disease}

\begin{tabular}{|c|c|c|c|}
\hline \multirow{2}{*}{ Baseline characteristics } & \multicolumn{2}{|c|}{ Type of Parkinson disease } & \multirow{2}{*}{$\mathrm{p}$} \\
\hline & Tremor dominant $(n=57)$ & Akinetic-rigid $(n=14)$ & \\
\hline \multirow[t]{2}{*}{ Female/male } & $22 / 35$ & $6 / 8$ & 0.770 \\
\hline & Median (25-75) & Median (25-75) & $\mathrm{p}$ \\
\hline Age & $73(65-78)$ & $72(69-76)$ & 0.839 \\
\hline Disease duration, years & $2(1-5)$ & $2(2-5)$ & 0.636 \\
\hline \multirow[t]{2}{*}{ H\&Y stage } & $2(1-2)$ & $3(2-4)$ & $0.001^{* * *}$ \\
\hline & $\mathrm{n}(\%)$ & $\mathrm{n}(\%)$ & $\mathrm{p}$ \\
\hline Right-sided symptom onset & $39(83)$ & $8(17)$ & 0.424 \\
\hline Left-sided symptom onset & $18(75)$ & $6(25)$ & 0.424 \\
\hline Dyskinesia & $7(70)$ & $3(30)$ & 0.378 \\
\hline Tremor & $57(95)$ & $3(5)$ & $0.001^{*}$ \\
\hline Restless leg syndrome & $17(81)$ & $4(19)$ & 0.927 \\
\hline Right sided carpal tunnel syndrome in ENMG & $21(75)$ & $7(25)$ & 0.367 \\
\hline Left sided carpal tunnel syndrome in ENMG & $22(81.5)$ & $5(18.5)$ & 0.842 \\
\hline Right cubital tunnel syndrome in ENMG & $9(100)$ & $0(0)$ & 0.112 \\
\hline Left cubital tunnel syndrome in ENMG & $8(88.9)$ & $1(11.1)$ & 0.487 \\
\hline
\end{tabular}


Table 2. Comparison of entrapment neuropathy and initially affected side in two types of Parkinson disease

Initial symptom side and type of Parkinson disease

Type of compressive neuropathy

Carpal tunnel syndrome, n (\%)

Cubital tunnel syndrome, n (\%)
Tremor dominant

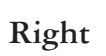

19 (76)

$10(76.9)$

\section{Left}

6 (24)

$3(23.1)$
Akinetic-rigid

Right Left

$3(42.9)$

4 (57.1)

$\mathrm{p}$

$0(0)$

$1(100)$

Table 3. Frequency of carpal tunnel and cubital tunnel syndrome according to disease duration

Parkinson disease duration (years)

\begin{tabular}{|c|c|c|c|c|c|c|}
\hline \multirow[t]{2}{*}{ Type of compressive neuropathy } & \multicolumn{2}{|c|}{ Tremor dominant } & \multirow{2}{*}{$\mathrm{p}$} & \multicolumn{2}{|c|}{ Akinetic-rigid } & \multirow{2}{*}{$\mathrm{p}$} \\
\hline & $<3$ years & $\geq 3$ years & & $<3$ years & $\geq 3$ years & \\
\hline Carpal tunnel syndrome, n (\%) & $9(36)$ & $16(64)$ & $0.026^{*}$ & $4(57.1)$ & $3(42.9)$ & 0.704 \\
\hline
\end{tabular}

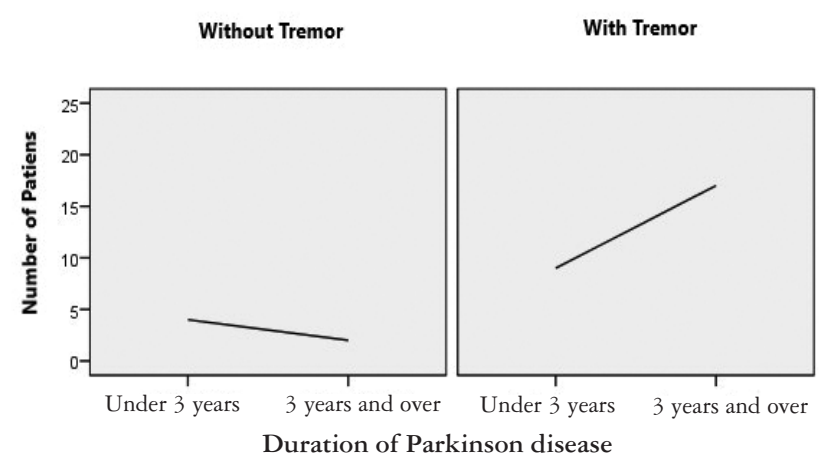

Figure 1. The relationship between the frequency of carpal tunnel syndrome and disease duration in patients with and without tremors

\section{Discussion}

In this study, a significant difference was found between the two groups in terms of the H\&Y stage in all 71 patients with PD, who were examined in two groups as TD and ARS. This difference was attributed to the more severe course of the ARS. Patient examination according to the H\&Y scale revealed that $61 \%$ of patients were in stages 1 and 2 .

The electrophysiological evaluation revealed that CaTS was diagnosed in $32(45.1 \%)$ and CuTS in $14(19.7 \%)$ patients. The two groups (TD and ARS) of patients with PD evaluated in our study showed no significant difference in terms of the affected hand and types of CN (CaTS and CuTS). Our study revealed a significant difference between the disease duration over the 3 years and the development of CaTS in the TD group.

Generally, the relationship between CaTS and PD remains arguable. Contrarily, patients with PD had a high prevalence $(55 \%)$ of CNs (8). The prevalence of CaTS in the normal population was reported as 125-220 per 100,000. The prevalence of CaTS in PD was precisely unknown; however, CaTS was diagnosed in $24.4 \%$ of patients in a study (9). In addition, Yucel et al. (10) found a higher CaTS prevalence in patients with PD compared to healthy people.
Repetitive arm usage is a well-known cause of CaTS. Moreover, CaTS symptoms improved with reduction of repetitive hand activity (11).

Yardimci et al. (12) reported this period to be 6 years in their study. In addition, no relationship was found between the side of the tremor or rigidity and $\mathrm{CN}$ incidence. Han et al. (13) stated that the repetitive hand activities with tremors cause CaTS, particularly in patients with TD PD. Our study showed that this difference was evident only when patients suffered longer from the symptoms of the disease.

Conflicting results were found in the literature when the relationship between the hand with $\mathrm{PD}$ symptoms and the hand with $\mathrm{CN}$ was examined. For example, Han et al. (13) claimed that early PD diagnosis prevents CaTS by reducing overuse of the asymptomatic side in TD PD. Yardimci et al. (12) investigated the relationship between the severity of symptoms and the development of entrapment neuropathy but did not find any relationship between the symptoms, duration, and stage of PD and CuTS. According to this theory, patients suffering from PD will not use the side dominated by ARS, thus $\mathrm{CNs}$ are more frequently seen in the opposite hand. Studies related to $\mathrm{CN}$ of patients with PD compared the study data by calculating the conduction values (by $\mathrm{m} / \mathrm{s}$ ) in ENMG. Nevertheless, our study classified this conduction data appropriately for clinical use. Statistically significant differences were found in comparison of conduction velocities (measured in $\mathrm{m} / \mathrm{s}$ ) in these studies; however, no clinical difference was found when these conduction values were classified clinically as mild, moderate, and severe $\mathrm{CN}$ in our study. The statistical data on this issue was insufficient to obtain a meaningful result in our study due to the small number of patients with CuTS (14).

\section{Study Limitations}

Our study had some limitations. First of all, our findings should be confirmed with a cohort study with larger patient groups. Second, the type and severity of the symptoms were primarily evaluated; however the lack of evaluation of medical therapy (dosage and effect of levodopa or similar drugs) was another limitation of our study. 


\section{Conclusion}

No relationship was found between the two different types of PD or the affected side and the type of CN. However, the risk of CaTS increased in the TD PD over the 3 years. Further clinical, studies with more detailed long-term clinical outcomes evaluating TD and ARS would provide additional results.

\section{Ethics}

Ethics Committee Approval: Approval with reference number 203 was obtained on November 16, 2017, from the Suleyman Demirel University Faculty of Medicine Ethics Committee for the study. This study followed the rules of the 2008 Declaration of Helsinki.

Informed Consent: Informed consent was obtained.

Peer-review: Externally peer-reviewed.

\section{Authorship Contributions}

Surgical and Medical Practices: N.Ş., A.Ö., E.T., Concept: N.Ş., Design: N.Ş., H.R.K., Data Collection or Processing: N.Ş.,E.T., Analysis or Interpretation: N.Ş., A.Ö., H.R.K., Literature Search: N.Ş., A.Ö., H.R.K., E.T., Writing: N.Ş.

Conflict of Interest: The authors have not declared any conflict of interest related to this article.

Financial Disclosure: No financial support was received from any institution or person for our study.

\section{References}

1. Massano J, Bhatia KP. Clinical approach to Parkinson's disease: features, diagnosis, and principles of management. Cold Spring Harb Perspect Med 2012;2:a008870.
2. Nutt JG, Wooten GF. Diagnosis and initial management of Parkinson's disease. N Engl J Med 2005;353:1021-1027.

3. Zhang J, Wei $\mathrm{L}, \mathrm{Hu} \mathrm{X}$, et al. Akinetic-rigid and tremor-dominant Parkinson's disease patients show different patterns of intrinsic brain activity. Parkinsonism Relat Disord 2015;21:23-30.

4. Tapadia M, Mozaffar T, Gupta R. Compressive neuropathies of the upper extremity: update on pathophysiology, classification, and electrodiagnostic findings. J Hand Surg Am 2010;35:668-677.

5. Assmus H, Antoniadis G, Bischoff C. Carpal and cubital tunnel and other, rarer nerve compression syndromes. Dtsch Arztebl Int 2015;112:14-26.

6. Anouti A, Koller WC. Tremor disorders. Diagnosis and management. West J Med 1995;162:510-513.

7. Padua L, LoMonaco M, Gregori B, et al. Neurophysiological classification and sensitivity in 500 carpal tunnel syndrome hands. Acta Neurol Scand 1997;96:211-217.

8. Loizon M, Laurencin C, Vial C, Danaila T, Thobois S. High incidence of carpal tunnel syndrome after deep brain stimulation in Parkinson's disease. J Neurol 2016;263:2416-2418.

9. Mengi-Ozsarac G. Carpal tunnel syndrome in Parkinson's disease. Eur J Radiol 2008;67:550.

10. Yucel A, Yilmaz O, Babaoglu S, Acar M, Degirmenci B. Sonographic findings of the median nerve and prevalence of carpal tunnel syndrome in patients with Parkinson's disease. Eur J Radiol 2008;67:546-550.

11. Alanazy MH. Clinical and electrophysiological evaluation of carpal tunnel syndrome: approach and pitfalls. Neurosciences (Riyadh) 2017;22:169-180.

12. Yardimci N, Cemeroglu O, Ozturk E, et al. Median and Ulnar neuropathy assessment in parkinson's disease regarding symptom severity and asymmetry. Parkinsons Dis 2016;2016:4958068.

13. Han SW, Cheon KY, Kim JY, Baik JS. Carpal tunnel syndrome in patients with tremor dominant Parkinson's disease. PLoS One 2015;10:e0130779.

14. Zis P, Grunewald RA, Chaudhuri RK, Hadjivassiliou M. Peripheral neuropathy in idiopathic Parkinson's disease: A systematic review. J Neurol Sci 2017;15;378:204-209. 